\title{
Application of Nanotechnologies in Poultry Production
}

\author{
Talaat Mostafa El-Sheikh* \\ Head of Poultry Production Department, Egypt
}

Submission: September 16, 2017; Published: September 20, 2017

*Corresponding author: Talaat Mostafa El-Sheikh, Head of Poultry Production Department, Faculty of Agriculture, Sohag University, Egypt, Tel: +2010033250107; Email: Talatm2@yahoo.com

\section{News}

In recent years, nanotechnologies have been applied more and more in the field ofanimal production. Notonly canitimprove animal immunity, oxidation resistance, and production and decreased antibiotic use and manure odor, which is conducive to bring environment improvement. The resistance of bacteria towards traditional antibiotics currently, constitutes one of the most important health care issues with serious negative impacts in practice. Clean and healthy farms are the premise of the healthy growth of livestock and poultry, which is also very important for the safety and health of staff and improvement of the surrounding air and water environments. Overcoming this issue can be achieved by using antibacterial agents with multimode antibacterial action. Silver nano-particles (AgNPs) are one of the well-known antibacterial substances showing such multimode antibacterial action.

Nano trace element may enter the animal body through direct penetration; therefore, its utilization rate is much higher than that of the ordinary inorganic trace elements. Research has shown that the utilization coefficient of inorganic trace elements was about $30 \%$, while the utilization coefficient of nano trace element was close to $100 \%$. It was demonstrated that nano Se has strong effects on improving the health of livestock, poultry, and fish, promoting growth, and improving feed conversion rate and other aspects. Nano Se exhibited strong nutritional and biological effects on improving the growth performance of chicken, If the calcium carbonate was crushed to the nano level, then the absorption and utilization rate of calcium could be significantly improved. Nano-selenium has the advantages of high absorption rate, high security, high antioxidant capacity, high egg-laying capacity, and good growth performance, and the range between nutrition dose and toxic dose of nano-selenium is significantly wider than that of sodium selenite. The toxicity of nano-selenium is lower than that of selenomethionine, and its toxicity is currently the lowest of all selenium supplements

The nano di-calcium phosphor, vitamin D3 and ordinary vitamin D3 were added to the feed of laying hens. Mannan oligosaccharides nano-liposomes can increase the average daily gain of healthy chickens, lower feed conversion. The average daily weight-gain were significantly higher than flavomycin control group $(\mathrm{P}<0.01)$. Mannan oligosaccharides nano-liposomes can regulate the immune function of chicken and play the role of resisting disease and promoting growth. There is shortage knowledge in use of nanotechnology innovation in egg poultry production sector. Poultry meat and eggs are often the source food borne pathogens, like salmonella. Early detection of food borne pathogenic bacteria is critical to prevent disease outbreaks and preserve public health. Role of nanotechnology in designer eggs, designer eggs are already in the market. In future the share of the designer eggs in the total share of the egg market will rise to more than $30 \%$ in 2020 . By 2000 market has to supply the cholesterol free eggs, yolkless or reduced yolk eggs which can be the high value protein source, immune eggs which can supply the predetermined antibodies and therapeutic eggs with supply the predetermined physiological factors for treatment purposes. 
CC Commons Attribution 4.0 License BY DOI: $10.19080 / \mathrm{NFSIJ} .2017 .03 .5555610$
Your next submission with Juniper Publishers will reach you the below assets

- Quality Editorial service

- Swift Peer Review

- Reprints availability

- E-prints Service

- Manuscript Podcast for convenient understanding

- Global attainment for your research

- Manuscript accessibility in different formats

( Pdf, E-pub, Full Text, Audio)

- Unceasing customer service

Track the below URL for one-step submission https://juniperpublishers.com/online-submission.php 